\title{
THE FifTH MileStone IN THE DEVELOPMENT OF \\ Chinese Language
}

\author{
Mateja PETROVČIČ \\ University of Ljubljana, Faculty of Arts, \\ Department of Asian and African Studies \\ mateja.petrovcic@ff.uni-lj.si
}

\begin{abstract}
Chinese language has undergone drastic in the past century. Papers on the language development stress four big events in the Chinese history that imposed changes on the language, i.e. The May Fourth Movement (1919), establishment of the People's Republic of China (1949), Cultural Revolution (1966), and China's reform and opening (1978). According to the features of recent neologisms, we suggest that the widening gap between rich and poor should be considered as the fifth milestone for changes in Chinese language.
\end{abstract}

Keywords: Chinese; neologisms; language development; social gap

\section{Izvleček}

Kitajski jezik se je v zadnjem stoletju korenito spremenil. V študijah zasledimo opažanja, da so ga močno zaznamovali štirje zgodovinski dogodki, ki predstavljajo mejnike v razvoju sodobne kitajščine. To so bili Gibanje 4. maja (1919), ustanovitev Ljudske republike Kitajske (1949), Kulturna revolucija (1966) in politika odpiranja Kitajske (1978). Glede na lastnosti neologizmov zadnjih let lahko rečemo, da se je izoblikoval peti mejnik v razvoju jezika, in sicer naraščajoče socialne razlike oz. razkorak med bogatimi in revnimi.

Ključne besede: kitajščina; neologizmi; razvoj jezika; družbeni razkorak

\section{Major Milestones for Language Changes}

Scholars agree that four big events in the history of China imposed changes onto Chinese language. The first milestone was 1919, when the May Fourth Movement took place; the second one was 1949, when People's Republic of China was founded; the third milestone was Cultural Revolution in 1966, and the fourth milestone dates to 1978, when China launched the policy of reforms and opened up to the outside world (Li, 2008; Sheng, 2009; Wu, 2006; Zhang, 2007). Zhang (2007) further noticed that since 1978, Chinese people have been welcoming new things and concepts with such

Acta Linguistica Asiatica, 3(1), 2013.

ISSN: 2232-3317, http://revije.ff.uni-lj.si/ala/

DOI: 10.4312/ala.3.1.61-74 
eager as never before. As a result, numerous new expressions in the fields of politics, economics, science and technology, social life etc. have appeared.

In addition to the above-mentioned milestones, some research papers point out the expansion of computers, internet and the development of information-communication technologies. It is to be agreed with $\mathrm{Wu}(2006, \mathrm{p}$. 24) that a variety of new products on this field leads to the corresponding Chinese expressions, and Han (2011, p. 99) that the rapid development of Internet technology has enabled the rise of numerous netizens which continuously create vivid forms of Chinese Internet language, and thus have an important impact on Standard Chinese. In other words, internet as the medium for spreading news can be seen as the cradle of new words and expressions.

This study proposes that the present social-economic situation with the widening gap between rich and poor may be considered as the fifth milestone for changes in Chinese language. According to the reports in The Economic Times, following Global Times and the Beijing News, the Gini coefficient ${ }^{1}$ in China reached 0.438 at the end of 2010, whereas it was 0.275 in the $1980 \mathrm{~s}^{2}$. Coefficients that exceed 0.4 are thought to indicate a challenge to the country's stability. The widening gap between rich and poor is associated with great achievements for the reforms and opening-up policy that happened within the last three decades. The changes helped officials and business people to prosper, whereas a vast number of Chinese were left with meager monthly wages in a society whose living standards have reached higher brackets ("China faces instability risks as gap between rich, poor widens," September 17, 2012).

Chapter 3 below demonstrates that newly created words in Chinese reflect exactly the mentioned social problem.

\section{The Amount and Structure of New Words and Expressions}

Language as the communication tool meets the needs of its speakers; therefore, it has to be changing as to reflect new situations and tendencies in life. Social changes may affect grammar, but they are reflected most intensely in the vocabulary of language. As Wang (2011, p. 1) notes, "new words are social barometer as they mirror changes in a society. Whenever such a change happens, new words will come forth to describe it." The above-mentioned milestones have caused many changes in all fields of social life; ranging from economics, politics, science and technology, culture, education, medical care, information technology, everyday life etc. As shown in the

\footnotetext{
${ }^{1}$ The Gini coefficient is an index measuring inequality of income with a scale of zero to one, zero being totally equal and one being totally unequal. ("China faces instability risks as gap between rich, poor widens," September 17, 2012)

${ }^{2}$ For detailed figures of Gini index in China, see ("Index Mundi: China GINI Index," 2011) or consider (The World Factbook, 2012). The Economic Times also reports that since 2000, no official statistics about wealth gap have been released by National Bureau of Statistics, with the argumentation that the Gini index couldn't be calculated as the incomes of urban and rural residents are calculated separately. ("China faces instability risks as gap between rich, poor widens,” September 17, 2012) Further reasons are discussed in Chen et al. (2010).
} 
following paragraphs, even great historical events could not affect life in the same extent. New expressions from different decades carry different characteristics.

Newly created words and expressions have always attracted scholars and lexicographers. Whereas no presentable work on neologisms is available from the period before 1987, more than 30 dictionaries of neologisms were published in China since then (Su \& Huang, 2003). According to data, though incomplete, they vary in the scope, as well as in the inclusion criteria, and cover from 335 entries up to 20 thousand entries (Chao, 2004).

Scholars have noted that since China adopted the reforms and opening up policy up to the 1990s, more than 7000 new words were invented in Chinese. According to statistics, approximately 600 neologisms arose yearly in the 1980s, around 400 in the 1990s, and about 450 in the first ten years of the $21^{\text {st }}$ century (Lin, 2000 in: Lin \& Xie, 2012; Zhang, 2007, p. 2). Different studies show that the amount of neologisms appearing per year is more or less constant. $\mathrm{Xu}$ (2009) made a research for the period 1966-1990, Li (2008) for the period 1990-2005, and Hou and Zhou (2011) for the recent five years. See Table 1.

Table 1: New words per year (Data range: 1966-2010)

\begin{tabular}{||l|c|c|c|c|}
\hline & $\mathbf{1 9 6 6 - 1 9 6 7}^{3}$ & $\mathbf{1 9 7 7 - 1 9 9 0}$ & $\mathbf{1 9 9 0 - 2 0 0 5}^{\mathbf{1 9}}$ & $\mathbf{2 0 0 6 - 2 0 1 0}^{\mathbf{5}}$ \\
\hline $\begin{array}{l}\text { New words per year } \\
\text { (average) }\end{array}$ & 415 & 375 & 400 & 447 \\
\hline
\end{tabular}

Although the amount of new expressions per year is rather constant, the semantic distribution of new words varies significantly in different decades due to the belonging historical events. A brief overview is presented in the following sections.

\subsection{The May Fourth Movement}

The May Fourth Movement is primarily related to changes in conceptual and knowledge systems, and to the shift of values etc. In this period Europeanization of the Chinese language affected not only vocabulary, but also had a significant impact on the grammatical features of Chinese language. (Gunn, 1991; Zhang, 2004) Words like “democracy” (demokelaxi 德莫克拉西6), “science” (saiensi 赛恩斯7), “stick” (sidike 斯的克), “club” (julebu 俱乐部), “morphine” (mafei 吗啡), “rectification” (zhengfeng

\footnotetext{
${ }^{3}$ For data 1966-1967 and 1977-1990, compare (Xu, 2009, p. 19)

${ }^{4} \mathrm{Li}, 2008$, p. 5.

${ }^{5}$ Hou \& Zhou, 2011, p. 313.

${ }^{6}$ Word "democracy" was semantically translated into minzhu 民主 before the May Fourth Movement, and was later on phonetically translated into demokelaxi 德莫克拉西. Nowadays the term minzhu is used again. (Du, 2009, p. 61)

${ }^{7}$ Present Chinese expression for the word "science" is kexue 科学.
} 
整风), “test” (kaoyan 考验) etc. originate from this period. (for more examples, see $\mathrm{Xu}, 2009$, p. 19)

\subsection{People's Republic of China}

The establishment of People's Republic of China gave rise to several new expressions in the field of politics, e.g. "New Democracy" (xin minzhu zhuyi 新民主主 义), “Mao Zedong Thought” (Mao Zedong sixiang 毛泽东思想), “People’s Democratic Dictatorship" (Renmin minzhu zhuanzheng 人民民主专政), “Five Economic Sectors" (wu zhong jingji chengfen 五种经济成分), “Three-Anti and FiveAnti Campaigns" (san-fan wu-fan 三反五反), "Reform of the Three Industries" (san da gaizao 三大改造) etc. Social changes also affected everyday's life, where, for example, a new term "comrade" (tongzhi 同志) replaced the previous "mister" (xiansheng 先生) or “miss” (xiaojie 小姐). (Chao, 2004, p. 8)

\subsection{Cultural Revolution}

New expressions from the Cultural Revolution period had even stronger political connotations. Some of the mostly used phrases are “capitalist roader” (zouzi pai 走资 派), “rebel faction” (zaofan pai 造反派), “little red book” (hongbaoshu 红宝书), “Red Guard” (Hong Weibing 红卫兵), “relative family” (guanxihu 关系户), “antirevolutionary revisionism” (fan geming xiuzheng zhuyi 反革命修正主义), “Sweep Away All Demons and Monsters" (Huangsao yiqie niugui-sheshen 横扫一切牛鬼蛇神 ), etc. (Chao, 2004, p. 8)

The reason for the Cultural Revolution to be one of the milestones is a big turn in the distribution of new words. In this period, a large majority of new words were related to politics $(74.6 \%)$, whereas in the next decade only a few new expressions were coined in the same field (Wu, 2006, p. 24). See Figure 1 for distribution of neologisms in the period 1966-1967.

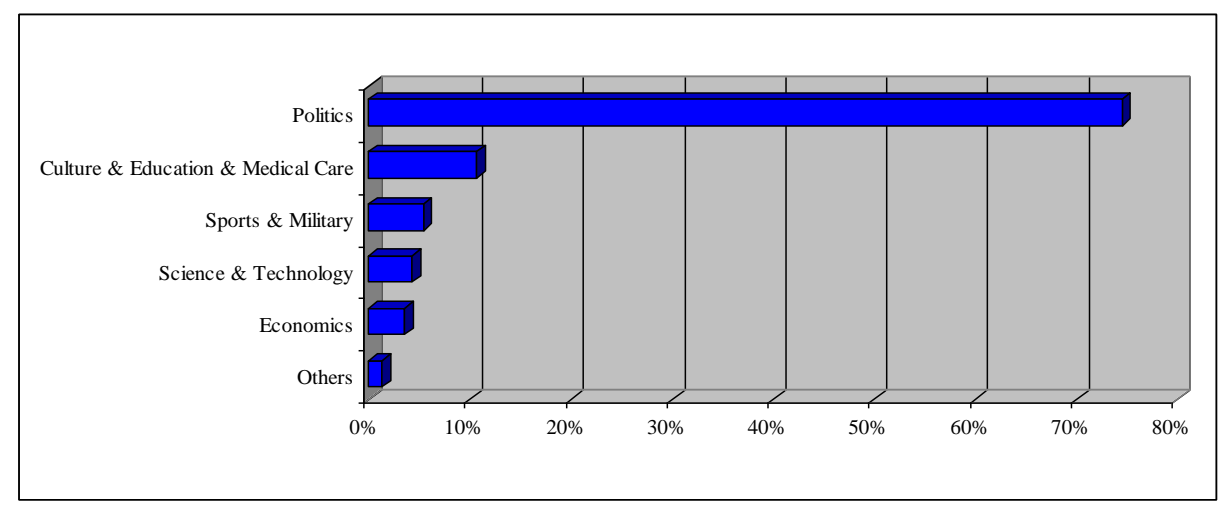

Figure 1: Distribution of neologisms in years 1966-1967 in \%;

(Based on Xu, 2009, p. 19) 


\subsection{Reform and opening up}

After China's reforms and its opening up, almost one third of the newly created expressions was related to economical concepts, e.g. "socialist market economy" (shehui zhuyi shichang jingji 社会主义市场经济), “Special Economic Zone” (Jingji tequ 经济特区), “Speed up reform” (jiakuai gaige 加快改革), “Open door policy” (kaifang zhengce 开放政策) etc. (Chao, 2004, p. 8)

China's contacts with foreign countries influenced not only economics, but also had a large impact on other fields of life. Therefore, Chinese language absorbed several new words and expressions, e.g. “clone” (kelong 克隆), “cartoon” (katong 卡通), “email” (yimeir 伊妹儿), “internet” (yintewang 因特网), “mini skirt” (mini qun 迷你裙), “soft drink” (ruan yinliao 软饮料), “human rights" (renquan 人权) etc. (Huang, 2009, p. 188) See Figure 2.

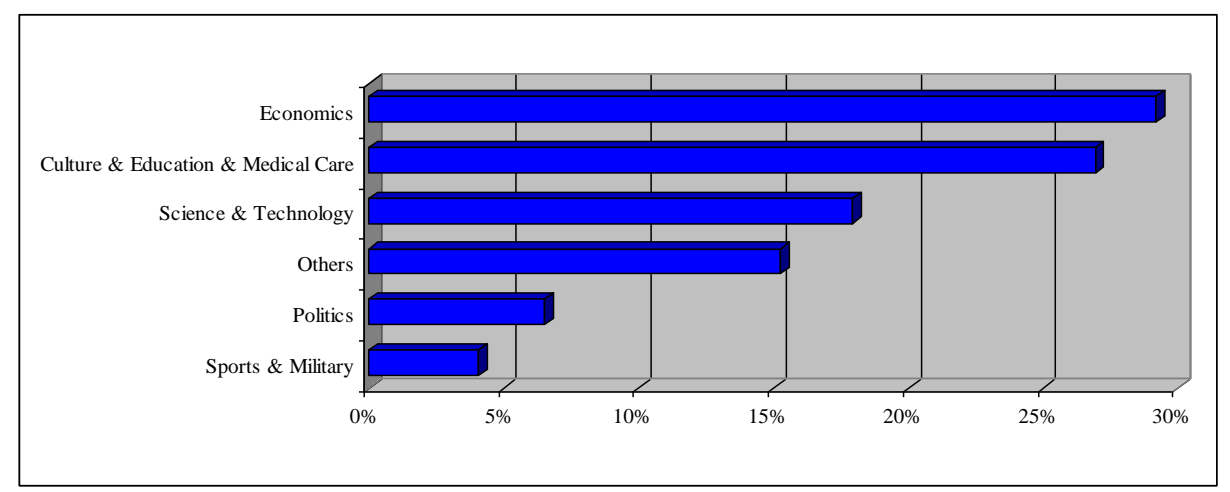

Figure 2: Distribution of neologisms in years 1977-1990 in \%;

(Based on Xu, 2009, p. 19)

Moreover, in the search of self-expression and through the refusal to follow others, people became very creative in language use. Old words that were thought of as "worn out" and were replaced with new ones which carried a taste of uniqueness. (Yuan, 2006, pp. 42-43) As mentioned in Chapter 1, people welcomed new things and concepts with such eager as they never did before. If the previous system was described as “communal pot" (daguofan 大锅饭) or "iron rice bowl” (tiefanwan 铁饭 碗), the new situation was called porcelain "rice bowl" (cifanwan 瓷饭碗). (Yuan, 2006, p. 43)

In the period 1990-2005, this trend was even more evident. According to Li's (2008) research results, the largest amount of new words was related to economics, finance and business, whereas social life became the second largest source for new expressions. Many new expressions were related to the field of news and communications, which is an expected trend, since new technologies enabled different channels for information flow. See Figure 3. 


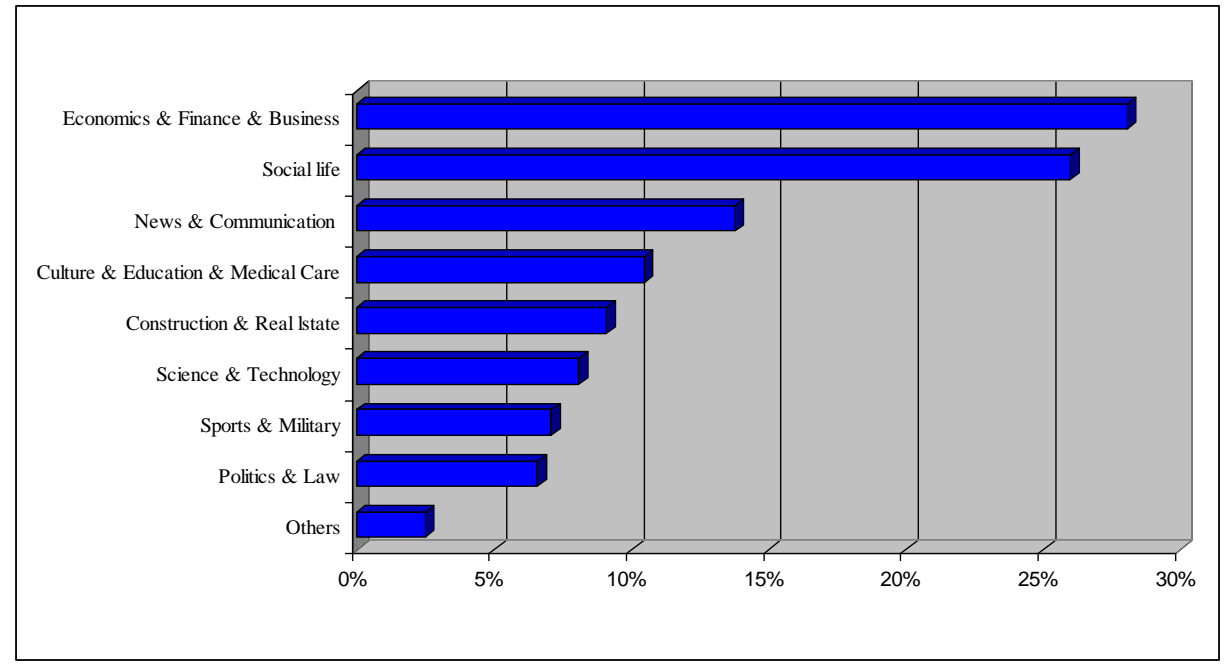

Figure 3: Distribution of neologisms in years 1990-2005 in \%;

(Based on Li, 2008, p. 20)

\section{The Fifth Milestone: Economic Inequality}

The importance of social life as a source of neologisms is even more obvious in the recent years. Wu and $\mathrm{Wu}$ (2012, p. 67) have noted that in year 2010, nearly $35 \%$ of all new expressions were related to social life. See Figure 4.

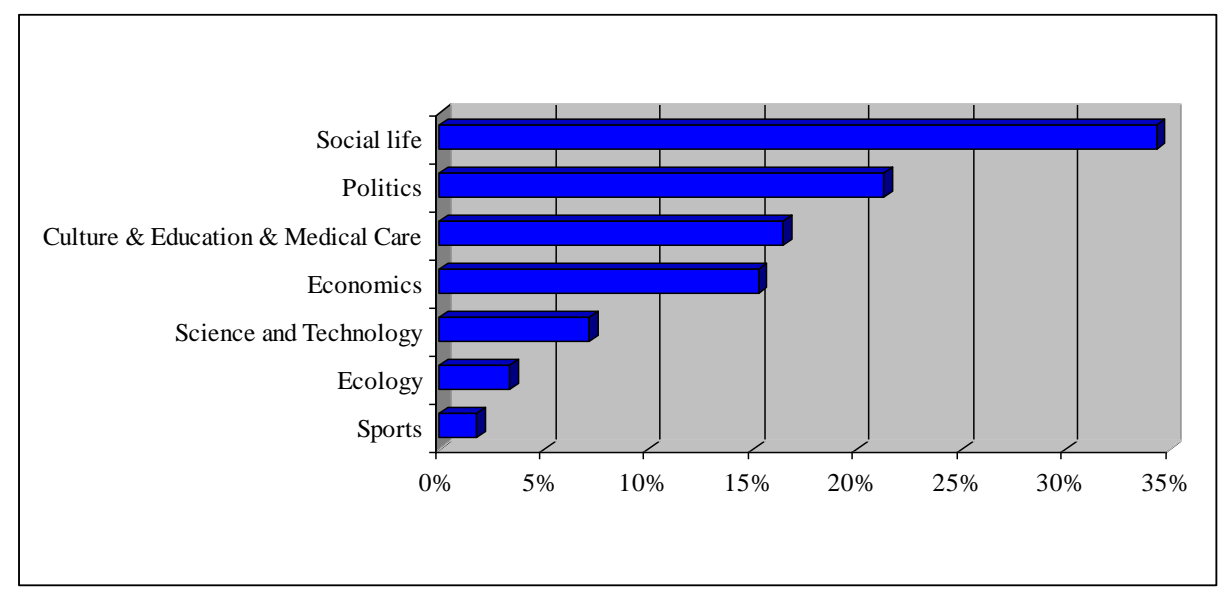

Figure 4: Distribution of neologisms in 2010 in \%;

(Based on T. 吴. Wu \& Wu, 2012, p. 67) 
However, in spite of the rapid economic growth and higher living standards, recently invented words and expressions reveal that Chinese citizens do not feel satisfied with the present quality of life. Numerous new words reveal dissatisfaction with the living conditions, and the trend of inventing the negatively loaded words is still growing. For example, several words indicate pressure, financial burden, unease, suspicion, fear and other similar feelings. Examples that support this observation is the productive use of morphemes like $n u$ (奴, “slave”) or bei (被 X, “being X-ed”).

\subsection{Various Slaves}

Character $n u$ (奴) which means "slave" is a very trendy tool to express one's negative attitude toward some situations. New words with $n u$ reveal that people feel like slaves about several things, for example:

- Fangnu (房奴), "house slave", “mortgage slave”.

A slave to one's mortgage. The person who works to pay off the loan used to buy a house.

- Chenu (车奴), “car slave”.

Somebody forced to sacrifice quality of life to buy or maintain a car.

- Hunnu (婚奴), “marriage slave”.

Due to high expenses of wedding ceremonies and banquets, a marriage is a huge financial burden. At the same time, people mostly feel obligated to get married.

It is worth noticing that the present pressure, requirements and expectations are frequently expressed in ways that are much more humorous and creative. For example, men are expected to have a house, car and wife, and those who achieve this goal are called zhuannan 孨男. Since the character zhuan 孨 consists of three 子, netizens apply it to refer to fangzi (房子, "house"), chezi (车子, “car”) and qizi (妻子, “wife”), while at the same time, character zhuan 孨 means "restpectful and prudent". Therefore this word also means successful self-starter who builds his career from scratch. As such, it could be translated as "ABC-man" (Apartment-Bride-Car) in English.

Other examples of $n u$-phrases include: cainu (菜奴, “food slave" - because of the increasing food prices), bainu (白奴, “white collar slave” - office worker who is overworked and exploited), jienu (节奴, “festival slave” - people who are overwhelmed by the pressure of socializing and giving away gifts during major Chinese traditional festivals), zhengnu (证奴, “slave of certificates" - people who are forced to take all kinds of exams to get as many certificates as possible to improve their qualifications and get a good job), among others.

\subsection{Being $X$-ed}

Roughly speaking, the bei-construction (被) in Chinese functions similarly to the English passive voice. This morpheme has recently become a very productive and widely used element. It expresses the meaning of something happening without 
someone's knowledge or agreement, or even that the situation is untrue and harmful. Zhang (2010, p. 87) understands numerous new expressions with bei as awakening awareness of civil rights and the lack of trust, while Liu (2010, p. 51) relates these words to empathy. On the other hand, Han (2011, p. 99) prefers looking at this phenomenon as the passiveness and helplessness of the socially weak people, whose voices cannot be heard. Some examples are:

- Beishanglou (被上楼), lit. "being flated", “being apartmented”.

The process of farmers being forced to give up their land by local governments and move into apartments is referred to as "going upstairs"

- Beishishi (被逝世) or beisiwang (被死亡), lit. “being recorded dead”. Hundreds of Chinese villagers were registered as dead and struck from village lists. By recording the false deaths, local officials held back payments.

- Beijiuye (被就业), lit. “being quasi-employed”.

Some universities are faking job contracts for their graduates to make sure graduate employment statistics remains high.

Further examples of bei-phrases are: beidiyi (被第一, "being reported as the (worst) first one”), beijianqiang (被坚强, “being toughened" (due to difficult life conditions)), beizhiyuan (被志愿, “being volunteered” (for a task against one's will)), beishangwang (被上网, “being (automatically) connected to the Internet" (and stolen money)), beijuankuan (被捐款, “being selected to donate money”) etc.

\subsection{Real Estate Market}

In addition to the above mentioned "mortgage slave" or closely related "rental slave", several words describe the problem of increasing urbanization and rising real estate prices. The following new words vividly describe the citizens' response to housing issue.

- Danxing woju (蛋形蜗居) or danju (蛋居), lit. “egg-shaped snail house”.

Dai Haifei, a 24-year-old architect in Beijing, found a solution to live rent-free. He built himself a mobile egg-shaped house that was powered by the sun. This structure, which was small enough to fit on a sidewalk, was made of bamboo strips, wood chippings, sack bags, and grass seed that's expected to grow in the spring.

- Dixia biaojian (地下标间), lit. “underground room”.

A retired Chinese coal miner Chen Xinnian, 64, from Zhengzhou, Henan province, has found an underground solution to the country's sky-high housing costs, by carving out a new home beneath the shack he lives in.

- Cunzhengfang (村证房), lit. “village-certificated house”.

Residence supposedly only transferable to other village residents but often sold on the open market. 
- Qunzu (群租), lit. “group renting” or “collective renting”.

Most migrant workers like to participate in the collective renting program as they cram as many people as possible into a small house in order to cut the share of the rent each has to pay.

- Qiuxuefang (求学房), “school-nearby house".

Many parents buy houses in the neighborhood of elite schools purely for the purpose of guaranteeing a better education for their children. According to the existing rules in many cities, primary and middle schools are only allowed to enroll students living in their neighborhoods.

On the other hand, rapid economic development has led to higher purchasing power and gave rise to various new expressions. Two examples from 2010 are "Peking Pound" (Beijingbang 北京镑) that is used for the money that Chinese spend overseas every year (Sun, January 2, 2011); and "Nth rich generation" ( $f u N$ dai 富 N 代), an expression for wealthy and prominent families. The latter term resembles "Second rich generation" (fu er dai 富二代) which describes children of entrepreneurs who became wealthy under 1980s economic reforms.

For the above-sketched reasons, this article proposes that the economic inequality should be considered as the fifth milestone in the language development that has promoted the social life to be the most important source for the creation of new words and expressions.

\section{Some Other Linguistic Features of Recent Neologisms (2006-2010)}

\subsection{The Amount of New Words}

Table 1 above shows that in the last five years around 450 words have been created annually. The more detailed analysis reveals that the amount of new words is increasing year by year. See Table 2.

Table 2: New words per year (Data range: 2006-2010)

(Hou \& Zhou, 2011, p. 313)

\begin{tabular}{|l|c|c|c|c|c|}
\hline & $\mathbf{2 0 0 6}$ & $\mathbf{2 0 0 7}$ & $\mathbf{2 0 0 8}$ & $\mathbf{2 0 0 9}$ & $\mathbf{2 0 1 0}$ \\
\hline New words per year & $171^{8}$ & 420 & 444 & 573 & 626 \\
\hline
\end{tabular}

We assume that these figures are slightly misleading, and do not purely indicate an increasing tendency in creating new words. Such numbers might be a result of more

\footnotetext{
${ }^{8}$ According to Wang (2007, p. 52), over 300 new expressions were invented in 2006, however, only 171 of them were extracted and officially presented to the public.
} 
sophisticated language technologies, larger databases, better query methods, different inclusion criteria etc.

Numerous new expressions are closely related to specific events. For example, in 2008, several new words arose because of Olympic Games in Beijing, Sanlu milk scandal, Sichuan earthquake and financial crisis. (Ren, 2009, p. 29)

These figures also include words for specific individuals that suddenly - on purpose or not - gained their five minutes of glory, for example "Brother Sharp" (Xilige 犀利哥, a homeless man in Ningbo) or “Peacock Dance” (Kongquege 孔雀哥, a performance in China's Got Talent), and are not very likely to become an established part of vocabulary.

The character men (门, gate) originates from the Watergate scandal and is nowadays commonly accepted as the word for "scandal", but several names of affairs will probably sink into oblivion very quickly, e.g. "Comment Scandal” (Jieshuomen 解 说门) from June 27, 2006.

In overall, this is still a very rough interpretation, and a more detailed research should be done to define accurate and reliable reasons for the increasing tendency in creation of neologisms.

\subsection{The Length and Structure of New Words}

According to Hou and Zhou's (2011) results, 3-syllable words are thought to be the most productive, whereas creation of 2-syllable words is a decreasing trend. The average length of new words and expressions is 3.2 characters. Compared to the previous century, words nowadays are undoubtedly longer.

Table 3 and Figure 5 provide a detailed situation of the length and structure of new words, and are based on data gathered in Hou and Zhou (2011, p. 313). Note that different researchers came to almost identical results. (Duan \& Zeng, 2010, p. 138; Wu \& Wu, 2012, p. 66)

Table 3: Distribution of N-syllable words per year (Data range: 2006-2010)

\begin{tabular}{||l|l|l|l|l|l||}
\hline \hline & $\mathbf{2 0 0 6}$ & $\mathbf{2 0 0 7}$ & $\mathbf{2 0 0 8}$ & $\mathbf{2 0 0 9}$ & $\mathbf{2 0 1 0}$ \\
\hline 2-syllable words & $34 \%$ & $22 \%$ & $17 \%$ & $19 \%$ & $17 \%$ \\
\hline 3-syllable words & $31 \%$ & $38 \%$ & $47 \%$ & $51 \%$ & $55 \%$ \\
\hline 4- or more-syllable words & $35 \%$ & $40 \%$ & $37 \%$ & $30 \%$ & $28 \%$ \\
\hline
\end{tabular}

\footnotetext{
${ }^{9}$ Only one one-syllable word was recorded in 2006 , therefore this category is omitted from the table.
} 


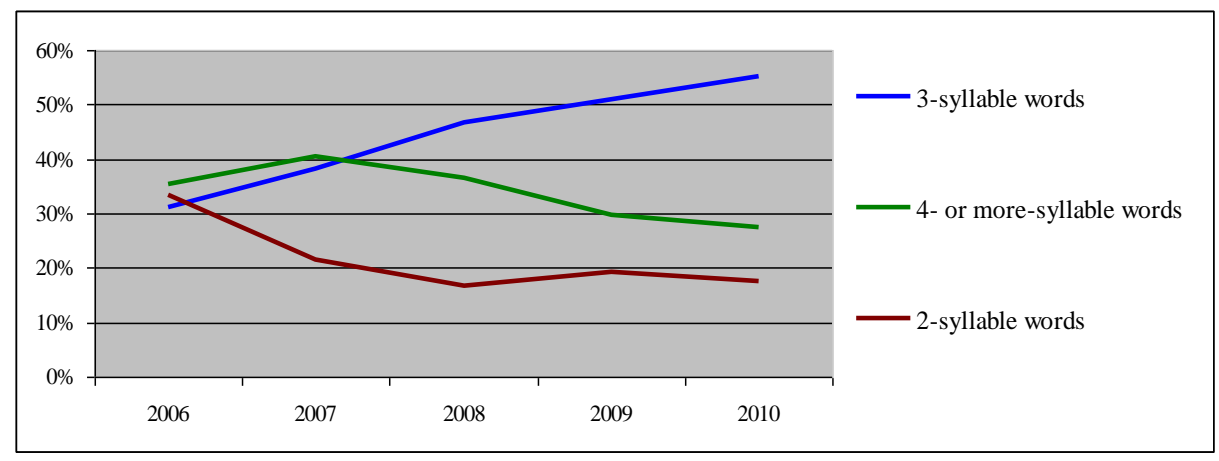

Figure 5: Distribution of N-syllable words per year (Data range: 2006-2010) - graphical presentation

Further analysis has shown that present neologisms generally reflect domestic needs, social situations, problems, formations or concepts, and do not refer much to ideas from abroad. Loanwords tend to be translated into Chinese semantically, or at least semantically and phonetically at the same time. Purely phonetic translations are quite rare.

\section{Conclusion}

Chinese neologisms vividly reveal the changes that China has undergone over the past decades. At the beginning of the 20th century, The May Fourth Movement deliberately "updated" and Europeanized Chinese language. The second big event that reshaped Chinese, was the establishment of the People's Republic of China and Cultural Revolution with the strongly enriched political vocabulary, whereas the economical sector became much more influential after the China's reforms and its opening to the world. These events are considered as the four milestones in development of Chinese language.

This paper has sketched the present social-economic situation and the widening gap between rich and poor, which engenders resentment, frustration, insecurity on one side, and huge purchasing power on the other side. The gap is thought to be a new turning point in the Chinese language development, with the field of social life to be the most important source for new words and expressions. Therefore, we propose the beginning of the 21 st century with its economic inequality to be the fifth milestone in the development of Chinese language. 


\section{References}

Chao, F. [巢峰] (2004). Tan Xinciyu cidian [谈新词语辞典]. Publishing Scinence [出版科学], $47(1), 8-11$.

Chen, J., Dai, D., Pu, M., Hou, W., \& Feng, Q. (2010). The trend of the Gini coefficient of China (Vol. 109). Manchester: Brooks World Poverty Institute.

China faces instability risks as gap between rich, poor widens. (September 17, 2012, 2012, October 3). The Economic Times Retrieved October 3, 2012, from http://articles.economictimes.indiatimes.com/2012-09-17/news/33902854_1_ginicoefficient-inequality-economic-reforms

Du, L. [杜丽丽] (2009). Cong wenhua jiechu de shijiao kan Hanyu zhong de yiyi wailaici [从文 化接触的视角看汉语中的意译外来词]. Journal of Puyang Vocational and Technical College [菐阳职业技术学院学报] (6), 60-62.

Duan, C. [段曹林], \& Zeng, C. [曾翠媚] (2010). “171 tiao xinciyu” gouci, yongci de dingliang fenxi [ “171 条新词语” 构词、用词的定量分析]. Journal of Hainan Normal University (Social Sciences) [海南师范大学学报(社会科学版)] 23, 137-144.

Gunn, E. M. (1991). Rewriting Chinese. Style and Innovation in Twentieth-Century Chinese Prose. Standford: Standford University Press.

Han, G. [韩贵强] (2011). “Bei XX” wangluo liuxingyu chutan [“被 xx”网络流行语初探]. Central China Normal University Journal of Postgraduates [华中师范大学研究生学报], 18(4), 99-102.

Hou, M. [侯敏], \& Zhou, J. [周荐] (2011). 2010 Hanyu xinciyu [2010 汉语新词语]. Beijing: Shangwu yinshuguan [商务印书馆].

Huang, F. [黄芳] (2009). Gaige kaifang 30 nian lai shehui liuxing de xinci xinyu ji qi guifanhua [改革开放 30 年来社会流行的新词新语及其规范化]. Jinri keyuan [今日科苑] (6), 188189.

Index Mundi: China GINI Index. (2011, March 2, 2011). Retrieved October 3, 2012, from http://www.indexmundi.com/facts/indicators/SI.POV.GINI/compare?country=cn

Li, K. [李科] (2008). Research on the Newly Born Vocabulary of Modern Chinese [现代汉语新 词研究]. Shandong University.

Lin, J. [林建平], \& Xie, X. [谢雪梅]. (2012). Xinci xinyu he putonghua jiaoxue [新词新语和 普通话教学]. Journal, 312-316. Retrieved from http://www.doc88.com/p576886562640.html

Liu, H. [刘红妮] (2010). “Bei XX” xinci de duojiaodu kaocha [ “被 XX” 新词的多角度考察]. Yuyan wenzi xueshu yanjiu [语言文字学术研究], 95(3), 49-53.

Ren, H. [任会芹] (2009). Qian tan 2008 nian wangluo xinci [浅析 2008 年网络新词]. Anhui wenxue [安徽文学], $8,326$.

Sheng, X. [盛香芹] (2009). Gaige chuqi Xiandai Hanyu de jubian [改革初期现代汉语的巨变]. Rencai ziyuan kaifa [人才资源开发] (7), 105-106.

Su, X. [苏新春], \& Huang, Q. [黄启庆] (2003). Xin ciyu de chengshu yu guifan cidian de xuanlu biaozhun. Tan “Xiandai Hanyu cidian" (2002 zengbuben) de “fulu xinci” [新词语 的成熟与规范词典的选录标准——谈《现代汉语词典》（2002 增补本）的 “附录新 词” ]. Cishu yanjiu [《辞书研究》]. (3), 106-113.

Sun, S. (January 2, 2011). British Media coined "Peking Pound" for Extravagant Chinese Purchases and High stakes Gambling Abroad Retrieved September 9, 2012, from 
http://www.chinahush.com/2011/01/02/british-media-coined-peking-pound-forextravagant-chinese-purchases-and-high-stakes-gambling-abroad/

Wang, H. [王红霞] (2011). A Contrastive Analysis of English and Chinese Neologism from the Perspective of Memetics.

Wang, M. [王铭宇] (2007). Yanjiu yu sikao: 2006 nian Hanyu xin ciyu [研制与思考: 2006 年 汉语新词语]. Yuwen jianshe [语文建设] 10, 52-53.

The World Factbook. (2012). Retrieved October 3, 2012. from https://www.cia.gov/library/publications/the-world-factbook/fields/2172.html.

Wu, L. [吴亮] (2006). A Research on Old Words New Meaning since the Beginning of Reform and Opening up [改革开放以来（1979 年-2005 年）的现代汉语旧词新义研究]. Shaanxi Normal University [陕西师范大学].

Wu, T. [吴制], \& Wu, X. [吴欣] (2012). 2010 nian Hanyu xinciyu yanjiu [2010 年汉语新词语 研究]. Yuwen yishu [语文艺术], 326, 66-68.

Xu, B. [许宝丹] (2009). The Analysis on Motivation of the Generating and Developing of Chinese New Words of New Period [新时期汉语新词语产生发展的动因探析] Unpublished M.A., Dalian University of Technology.

Yuan, Y. [袁园] (2006). 1990-2002 nianjian de jingjilei xinci touxi [1990-2002 年间的经济类 新词透析]. Nanjing Normal University [南京师范大学].

Zhang, J. [张京平] (2007). A Tentative Approach to the Chinese Neologism Translation in Recent Two Decades [近二十年汉语新词英译探析]. Central South University [中南大 学].

Zhang, M. [张明辉] (2010). Lun shixia liuxung goushi “bei XX” [论时下流行构式“被 XX”]. Journal of Guangdong Polytechnic Normal University [广东技术师范学院学报(社会科 学)] (3), 85-87.

Zhang, W. [张卫中] (2004). 20 shiji chu Hanyu de Ouhua yu wenxue de biange [20 世纪初汉 语的欧化与文学的变革]. Wenyi zhengming [文艺争鸣] (3), 38-44. 